Max-Planck-Institut für demografische Forschung

Max Planck Institute for Demographic Research

Konrad-Zuse-Strasse 1 - D-18057 Rostock - GERMANY

Tel +49 (0) 3812081 - 0; Fax +49 (0) 3812081 - 202;

http://www.demogr.mpg.de

MPIDR WORKING PAPER WP 2003-022

JULY 2003

\title{
Gender and Generations Dimensions in Welfare-State Policies
}

Gerda Neyer (neyer@demogr.mpg.de))

This working paper has been approved for release by: Jan M. Hoem (hoem@ demogr.mpg.de)

Head of the Laboratory of Contemporary European Fertility and Family Dynamics.

(C) Copyright is held by the authors.

Working papers of the Max Planck Institute for Demographic Research receive only limited review.

Views or opinions expressed in working papers are attributable to the authors and do not necessarily reflect those of the Institute. 


\title{
Gender and Generations Dimensions in Welfare-State Policies
}

\author{
Gerda Neyer \\ Max Planck Institute for Demographic Research \\ Rostock
}

This note outlines welfare-state research that could possibly provide a framework for the collection of demographically relevant gender- and generationsensitive welfare-state data for the GGS contextual database. It has been prepared for the Gender-and-Generations Program and is the basis of further work of the Contextual Working Group of the Gender-and-Generations Program.

First, this note summarizes results of demographic research that deals with the effects of public policies on demographic behavior. This is followed by a brief outline of what kind of data we need for (comparative) research of policy effects on demographic issues.

Secondly, it gives a brief account of those conceptualizations of the welfare state that seem relevant for the purpose of our project.

Thirdly, it presents a provisional and by no means complete list of some welfare-state-related measures that can be collected for a contextual database. This list serves as an example of what we need and how we should collect data in order to be able to incorporate features of welfare states and public policies in demographic analyses.

\section{Demographic research, public policies, and data requirements}

Demographers have repeatedly complained that their discipline has paid too little attention to political and institutional factors and to their influence on demographic behavior. There is some truth in this complaint. If we browse the literature on family and fertility (in highly industrialized countries), for example, we find rather few studies that take political factors into account compared to the bulk of research that deals with the demographic impact of economic or cultural (educational) issues. In addition, most studies that include politics investigate the effects of individual policies, usually of particular family policies. Studies of this kind have rendered ambivalent or even contradictory results. In most cases, researchers could discern no or only very small effects of policies on family and fertility behavior. The results were more pronounced if specific - usually significant - changes in policies were examined. Demographers have concluded from these findings that we may need to pay more attention to the interaction between various policies. Comparative empirical and theoretical research further suggests that two other factors may account for the varying effects of policies on demographic behavior. One is the institutional setting of policies, that is the way in which a particular policy is anchored in the social policy system of a country. Policies may reflect a particular type of welfare state, but 
they may also run counter to the general welfare-state politics of a country. The other factor is the cultural and economic context in which individual policies are embedded.

Our purpose, therefore, is to provide data that will allow us to investigate the interrelation between policies and their interaction with demographic issues. Furthermore, the database should allow us to test demographic theories that are related to the topics of the GGS (for example: theories of "female economic autonomy", of "relative economic deprivation", of "ideational change", of "wealth flow" etc.). Such an approach suggests that we need to develop a database that fulfils the following criteria:

1. It should allow us to form "clusters of policies" related to the demographic event at stake (e.g.: entry into parenthood, into marriage; divorce; leaving home; retirement; etc.).

2. It should contain information that may be linked to the main assumptions of demographic theories.

3. The database should provide data in time-series to allow for investigations of demographic change and their relationship with changes in public policies or politics. The time-series should be retrospective and cover the respondents' life span (from the age 15 onward).

4. It should provide data from a gender and generation perspective as well as from a life-course perspective. This implies that the database should contain genderspecific data as well as age-specific data and also collect data that apply to specific groups (women, mothers with small children, elderly, etc.).

5. It should provide data for comparative research, either through standardization of parameters or through extensive documentation of national idiosyncrasies.

6. The database should allow us to construct "contexts" so that we will be able to analyze the data of our questionnaire within an economic, cultural, political framework.

This note does not intend to devise such a comprehensive framework; we leave it to specialists in economic and cultural analyses of demographic behavior to design a framework for the collection of economic and cultural data necessary for demographic research. We limit ourselves to outlining a welfare-state approach to the collection of contextual data for multi-level analyses of demographic behavior. As will be shown below such an approach includes economic and cultural aspects and may thus be a good starting point for a comprehensive contextual database.

The choice of data to collect is partly determined by the way in which we conceive of the welfare state. Unfortunately, there is no explicit and universally accepted definition of the welfare state. The way in which researchers have defined the welfare state has largely been determined by two factors, namely, first by their theoretical and empirical interests in phenomena that are not necessarily specific to the welfare state and, secondly, by constraints in data availability and accessibility. Both factors have contributed to conceptualizations that a) largely neglect Eastern European countries and b) that are only partially relevant for demographic analysis. 
For our purpose we now give an account of those welfare-state definitions that may serve as a framework for demographic analyses, that offer links to demographic theories, and that are also applicable to the situation in Eastern and Central Europe.

\section{Social expenditure as a measure of welfare states}

The welfare state has often been described as a state that takes responsibility in providing basic economic and social security for its citizens. This conceptualization encompasses two different traditions in welfare-state research. One tradition rests on assumptions about poverty and basic needs; the other on assumptions about economic and social risks, most notably linked to market risks (unemployment, sickness, accident, invalidity) or to demographic risks (old age, childbearing, widowhood, single parenthood). Empirically, research that uses this definition measures welfare states according to their level of social expenditure. Social expenditure is often regarded as a rather crude measure for evaluating and comparing welfare states, not least because corresponding statistics often fail to elucidate the allocation of benefits and fall short of revealing the effects of welfare-state provisions on gender, class, race/ethnicity, or inter-generational relationships. Yet, as more refined data of social spending have become available, social expenditure proves to be a useful means of exposing the underlying principles of welfare states (Daly 2000) ${ }^{1}$. And it may be a valuable indicator of gender and generations paradigms governing welfare-state policies, especially in cases where we lack (comparable) data. For example, social expenditure figures may display whether a welfare state attributes more of its social spending to services for families or to individual family benefits; they may reveal whether mothers or fathers are the prime recipients of family benefits (Wennemo 1992/1994), they may show whether a state allots more of its social budget to the elderly or to youth (and families; Esping-Andersen 1999) or how much of the activelabor-market budget goes towards the integration of mothers into the labor market or to the integration of men (Streissler 1998).

\section{The welfare state as an answer to social problems}

A second strand of research defines the welfare state as a state that uses public policies to compensate for or prevent social and economic problems. The welfare state thus fulfils regulatory and redistributive functions and aims at attaining security and equality. Guiding research questions are: To what extent do welfare states grant economic and social security to their citizens? To what extent do welfare-state policies contribute to an equalization of the levels of living (equality of results) and to an equal distribution of life-chances (equality of opportunities) (Flora/Heidenheimer 1982/1995)? To what extent do welfare-state policies support an equal distribution of "agency" (equality of agency) and enhance a person's freedom to achieve functioning, to have well-being (Korpi 2000)? In general, this type of research uses a broader spectrum of indicators to classify welfare states. It includes additional realms of institutions (education, care, income, political institutions) and it classifies welfarestate provisions according to type, legal regulations, availability, and coverage. Security is measured in terms of the distribution of social security (health,

\footnotetext{
${ }^{1}$ The cited literature gives good examples of what to collect and how to collect.
} 
unemployment, old-age, maternity, invalidity insurance), such as the availability of social-security provisions for and the social-security coverage of different groups of the population (Preparing for an Aging world 2000). Equality of results, equality of opportunities, and equality of agency are assessed in terms of offers of social services (education, care services and care-leave provisions), income distribution, income redistribution through welfare benefits (e.g. family benefits, taxing), public presence and public representation of various groups of the population (e.g: female labor-force participation; female representation in the political sphere). The "equality - security paradigm" has also partly replaced the "poverty paradigm", especially in research that deals with specific groups of the population, such as lone mothers, single women, and older women. This research looks, for example, at the conditions that are attached to benefits (e.g.: constraints of personal freedom) (Lewis 1997).

\section{Welfare-state policies as structuring policies and the world of welfare- state regimes}

This research defines the welfare state as a state that uses (social) policies to structure society and its social and economic relationships. It views the state in relation to the market and the family, and asks how state activities are interlocked with these two institutions in shaping social conditions and providing social welfare. Comparative research based on this approach has shown that western welfare states group into distinct patterns of welfare-state regimes. The most prominent classification (Esping-Andersen 1990) distinguishes between

liberal welfare states (USA, Canada, Australia) which support market forces and offer only a minimum of social security;

conservative welfare states (Germany, France, Italy, Austria, the Netherlands) which offer social security, but their social policies are directed towards the support of status differences and traditional family forms; and

universal welfare states (Scandinavian countries) which grant social security on the basis of individual social rights and direct their social policies towards achieving greater equality in the public and the private sphere.

The basis for this classification is a set of indicators of social security arrangements (e.g.: conditions of entitlement, duration of benefit, minimum benefit, standard benefit, benefit replacement level; contribution period; waiting days for benefit) and organizational elements of the social security system (e.g.: private pensions (percentage of total pensions); means-tested poor-relief (percentage of total pensions); degree of universal coverage in the population, measured as percentage of the population (16-65) covered by the social insurance; etc.). The typology has been extended by other authors to include, e.g., southern European countries as a fourth welfare-state regime (familistic welfare states) or the Antipodean welfare states. More refined indicators about female/male labor-market participation, child-care provisions, etc. have further disclosed a great heterogeneity among the conservative welfare-state regimes and questioned whether they should be pooled together.

Feminist researchers have pointed out that although this classification is ostensibly based on an analysis of the interrelation between the state, the market, and the family in providing social security, it largely ignores gender relations and "the family". Feminist researchers have looked at the way in which welfare-state and other 
policies (social security regulations, parental-leave regulations; entitlements to benefits; inter-family recipients of benefits; care services; divorce regulations; labormarket and employment policies; gendered income distribution; tax regulations; school-systems; etc.) structure gender relations within families, the market, and society. Their work has discerned other typologies of welfare-state regimes, such as strong, modified, or weak male-breadwinner welfare states; male-breadwinner, dualbreadwinner, female-carer models of welfare states; maternal vs. fraternal welfare states; women-friendly welfare states, familializing vs. de-familializing welfare states (Lewis 1992; Orloff 1993; Daly 2001; Sainsbury 1999; Gornick et al 1997, Anttonen and Sipliä 1996)). It has pointed to the need to include care and the organization of care (e.g.: privately through unpaid work, usually done by women or (female) family members; privately through markets or semi-markets; public through welfare organizations; state-organized). Feminist research has further shown that there are links between welfare-state typologies and the socio-cultural context of society (PfauEffinger 1999). It has also stressed the importance of including body politics and reproductive politics (such as abortions regulations, legislation of sexual violence, same-sex legislation) in welfare-state research (O'Connor, Orloff, and Shaver 1999).

\section{Welfare states and Eastern Europe}

Eastern European countries are seldom included in welfare-state research. This is partly due to the lack of (comparable) data, partly to the fact that the interrelation between state, market, and family in former Eastern European countries differed significantly from the one in the West. Social policies in the Eastern European countries followed different ideological and institutional principles than in the Western European countries. During the first years of transition to democratic systems and (capitalist) market economies, most social policy measures, especially family policy measures, were maintained, although their organization changed (e.g.: services shifted from the workplace to the community). Some policies, such as unemployment policies, were newly introduced, some (like family benefits) were extended (mainly to compensate for the abolishment of price subsidies for basic goods), some were changed from universal to targeted policies or cut back. ${ }^{2}$ With the change in politics and economics, however, social policies have acquired quite different and - as far as demographic issues are concerned - often adverse effects (Fajth 1994; Gal and Kligman 2000). Researchers also point out that the revival of nationalism in Eastern Europe gave new directions to pro-natalist social policies and to the reproduction and gender policies in the region. The developments of the past 15 years suggest that Eastern European countries do not develop in a uniform way, but that several 'models' of welfare-state set-ups are emerging. For our contextual database it is important to collect data that grasps these changes. It is necessary to gather data prior to 1989 so that the demographic, the gender and generational effects of the changes may be better assessed.

\section{Gender and generations: welfare-state policies and demographic analyses}

Summarizing these different aspects we may address welfare-state effects on gender and generations in a demographic context from three different angles:

\footnotetext{
${ }^{2}$ The list of changes is not complete. There were also many institutional changes that had an impact on policies and policy outcomes.
} 
First, to what extent does the welfare state enable a person to enter into or exit from social and economic relationships (for example: labor-force participation; entry into parenthood; divorce) - in either case without significantly impairing her wellbeing or her standard of living?

Secondly, to what extent does the welfare state influence (that is produce or reduce) social and economic equalities (for example: equality between women and men and between the generations in all possible aspects) in the market, in society, and in the family?).

Thirdly, to what extent does the welfare state influence a person's social, economic, and personal rights? (For example: Are social rights tied to a specific status or granted universally? Does the state protect sexual freedom?).

These questions may serve as guidelines when we decide which data to collect for our data base. Structurally these questions are embedded in a framework in which the state, the market, society, and the family (= parenthood, partnership) form the 'pillars' of social organization in a nation-state.

Furthermore, we regard it as essential for a gender and generations survey to build on feminist research in developing a contextual database. Feminist research stresses the fact that social, political, and economic institutions - such as marriage, parenthood, care, employment, political institutions, policies, welfare-state regulations and so on - are not gender neutral, but gendered, that means structured and organized along gender lines. Women and men act within gendered institutions (in theoretical terms: they are 'doing gender' or 'opposing gender' within a gendered framework). To get a better insight into demographic behavior and national differences in demographic trends we therefore need to link women's and men's individual behavior to the gendered (national) social settings. Four dimensions seem to be of importance to grasp the gendered setting from a welfare-state perspective:

first, we need to view the state, the market, society, and the family from a gender perspective,

second, we need to introduce care as a gender-generation nexus into welfarestate analyses,

third, we need to differentiate between the distinct relationships in families (parenthood, partnership, and intergenerational relationships), and

fourth, we need to consider family law and legal provisions in welfare-state analyses.

Some might argue that neither a welfare-state concept as developed for western democracies nor feminist research are suitable to grasp the specificity of Eastern European societies and countries. From a theoretical point of view we see no problem in using feminist and western welfare-state approaches as theoretical frameworks for data collection. The feminist perspective implies viewing the statesocialist resp. transition countries from a gender perspective and also paying attention to issues that are usually regarded as women's issues (and therefore often neglected). The welfare-state approach calls for constructing a database that includes information within a state-market-society-family (couple/parenthood) framework. The fact that the 
relation between state-market-society-family was different during state-socialist times (and different for different countries in Eastern Europe) needs to be considered when analyzing the data, but this does not affect the usefulness of the general framework for the collection of data.

As an example for a guideline to collect data, I add a list for data collection that is structured along the major constituents of welfare states and welfare-state policies (state, market, society, and family), distinguishing between parenthood, partnership, intergenerational relationships on the family level. The list is not complete. (For the list see file: Datalist.doc)

\section{$\underline{\text { References: }}$}

Anttonen, A., J. Sipilä (1996): European social care services. Is it possible to identify models? In: Journal of European Social Policy 6/2, 87-100.

Daly, Mary (2000): A fine balance. Women's labor market participation in international comparison. In. Scharpf, Fritz W., Vivien A. Schmidt (eds.): Welfare and work in the open economy. Volume II. Diverse responses to common challenges. Oxford University Press, Oxford.

Daly, Mary (ed.) (2001): Care work. The quest for security. International Labour Office, Geneva.

Esping-Andersen, Gosta (1990): The three worlds of welfare capitalism. Princeton University Press, Princeton.

Esping-Andersen, Gosta (1999): The social foundations of postindustrial economies. Oxford University Press, Oxford.

Fajth, Gáspár (1994): Family support policies in transitional economies: Challenges and constraints. Economic Policy Series 43. UNICEF.

Flora, Peter, Arnold J. Heidenheimer (1982/1995): The development of welfare states in Europe and America. Transaction Publishers. New Brunswick/London.

Gal, Susan, Gail Kligman (eds.) (2000): Reproducing gender. Politics, publics, and everyday life after socialism. Princeton University Press, Princeton.

Gornick, Janet.C., Marcia.K. Meyers, Katherin.E. Ross (1997): Supporting the employment of mothers: policy variations across fourteen welfare states. In: Journal of European Social Policy 7/1, 45-70.

Korpi, Walter (2000): Faces of inequality: Gender, class, and patterns of inequality in different types of welfare states. In: Social Politics 7/2 (summer).

O’Connor, Julia S., Ann Shola Orloff, Sheila Shaver (1999): States, markets, families. Gender, liberalism and social policy in Australia, Canada, Great Britain and the United States. Cambridge University Press, Cambridge.

Orloff, Ann Sh. (1993): Gender and the social rights of citizenship: The comparative analysis of gender relations and welfare states. In: American Sociological Review 58/3, 303-328. 
Preparing for an aging world. The case for cross-national research (2001): National Research Council, National Academy Press, Washington.

Sainsbury, Diana (ed.) (1999): Gender and welfare state regimes. Oxford University Press, Oxford.

Wennemo, Irene (1994): Sharing the costs of children. Swedish Institute for Social Research 25, Edsbruk. 